\title{
The Northumbrian Attack on Brega in A.D. 684
}

\author{
David A.E. Pelteret
}

One of the most puzzling episodes in the history of Northumbria is the attack on Brega in the midlands of Ireland instigated by Ecgfrith, king of the Northumbrians, in the year before he died. Anglo-Saxon sources do not mention any reason for the attack. This chapter suggests that Ecgfrith's motive lay in the nature of his kingdom at the time and that this explanation is consonant with Irish annalistic evidence. ${ }^{1}$

\section{Sources}

The report of the attack on Brega in the Irish Annals is laconic: for example, the Annals of Ulster, s.a. 685.2 states: "The Saxons lay waste Mag Breg, and many churches, in the month of June." ${ }^{2}$ Fortunately the Venerable Bede, writing in a judgmental passage imbued with over four decades of hindsight, provides in his Historia ecclesiastica IV.26 a few fragments of additional information that are relevant:

In the year of our Lord 684 Ecgfrith, king of Northumbria, sent an army to Ireland under his ealdorman Berht, who wretchedly devastated a harmless race that had always been most friendly to the English, and his hostile bands spared neither churches nor monasteries. The islanders resisted force by force so far as they were able, imploring the merciful aid of God and invoking His vengeance with unceasing imprecations.

After relating how Ecgfrith was killed the next year, on 20 May, in an attack on the Picts that his friends had advised against, Bede says that

1 Later sources dealing with the impact of the attack on Brega are not discussed here. For admirable introductions to these sources see Patrick Wadden, "The First English Invasion: Irish Responses to the Northumbrian Attack on Brega, 684," Ríocht na Midhe 21 (2010), 1-33, and "Trácht Romra and the Northumbrian Episode in Betha Adamnáin," Ériu 62 (2012), 101-11.

2 "Saxones Campum Bregh uastant 7 aeclesias plurimas in mense Iuni": The Annals of Ulster (To A.D. 1131), Part 1: Text and Translation, ed. and trans. Seán Mac Airt and Gearóid Mac Niocaill (Dublin, 1983) [hereafter $A U$ ], pp. 148-49. 
... in the previous year he had refused to listen to the holy father Egbert, who had urged him not to attack the Irish who had done him no harm; and the punishment for his sin was that he would not now listen to those who sought to save him from his own destruction. ${ }^{3}$

Unfortunately Bede does not disclose where he obtained his information. Its ultimate source may have been the monk Ecgbert himself. Ecgbert had originally retired as a peregrinus to Ireland ${ }^{4}$ to the monastery of Rath Melsigi. ${ }^{5} \mathrm{He}$ was a supporter of the Dionysiac Paschal tradition and is referred to by Bede in several places in his Historia ecclesiastica. ${ }^{6}$ For reasons undisclosed he eventually moved to the monastery on the island of Iona in 716 , where he is credited by Bede with converting the monastic community there to the Dionysiac Easter and the adoption of the Petrine tonsure. ${ }^{7}$

\section{Northumbria: The Setting}

Northumbria in the reign of Ecgfrith was still in anthropological terms at a stage of social development more akin to a chiefdom than a state. ${ }^{8}$ To begin with, it did not have stable borders. Even Northumbria itself as a consolidated realm was a recent creation, the southern territory of Deira having been finally incorporated into Bernicia in the north under Ecgfrith's father Oswiu less than twenty years before Ecgfrith acceded to the throne of the Northumbrians. Northumbria's northern border is difficult to define in his reign. ${ }^{9}$

3 Bede, $H E$ IV.26(24), pp. 426-29.

4 Bede, $H E$ III.4, pp. 224-25

5 On the monastery see Dáibhí Ó Cróinín, "Rath Melsigi, Willibrord and the Earliest Echternach Manuscripts," with an appendix by Thomas Fanning, "Some Field Monuments in the Townlands of Clonmelsh and Garryhundon, Co. Carlow," Peritia 3 (1984), 17-49.

6 Bede, $H E$ III.4, 27; IV.3, 26(24); v.9, 10, 22, 23, 24, pp. 224, 312, 344, 428, 474-80, 554, 556, 566 . He may, in fact, have had episcopal status: cf. Bede, $H E$, p. 225 n. 3. See also Bede, De temporum ratione, cap. 66, s.a. 4670, in C.W. Jones, ed., Bedae opera didascalica, 2, CCsL 123B (Turnhout, 1977), pp. 532-33 (a reference I owe to Dr Daniel Mc Carthy).

7 Bede, $H E$ v.22, p. 554. Bede's reference to its island location is important because it shows that Ecgbert kept his vow not to return to his "native island Britain" (Bede, HE III.27, pp. 312-13).

8 For chiefdoms see Elman R. Service, Primitive Social Organization: An Evolutionary Perspective, 2nd ed. (New York, 1971), Ch. 5 and for some key characteristics of a state see D. Blair Gibson, From Chiefdom to State in Early Ireland (Cambridge, 2012), pp. 279-81, though naturally as in any discipline there is a diversity of opinion among anthropologists.

9 See Peter Hunter Blair, "The Bernicians and their Northern Frontier," in Studies in Early British History, ed. Nora K. Chadwick (Cambridge, 1954), pp. 137-72, esp. pp. 169-72, repr. in Peter 
As for the south, sometime in the 670s Ecgfrith and his younger brother Ælfwine, who was apparently ruling Deira, granted Wilfrid certain lands that had been under the control of the British church. Specifically named are Yeadon and the region of Dent and Catlow. ${ }^{10}$ How far these regions were actually under the direct sway of the two Northumbrian kings may be questioned. Wilfrid was an aggressive cleric pursuing a Romanist agenda in Northumbria but he had only seven or eight years at most to establish in these regions churches that adhered to Roman practices before he was ousted from his bishopric by Ecgfrith in 678.1

How much control Ecgfrith exercised over the territory to the west abutting the Irish Sea is uncertain. Nick Higham talks of "Northumbrianization," implying it was a gradual process. He has suggested that the Mersey was its southern frontier "from the later decades of the seventh century" but unfortunately there is no firm evidence for this. ${ }^{12}$ Even if he is correct, this does not mean that the area was under Ecgfrith's control in the 67os and early 68os. In the southeast of his realm Ecgfrith suffered a severe military defeat at the hands of the Mercians in 679 at the River Trent, where effectively he lost control of the territory of Lindsey. We shall return to this defeat later.

Three further factors should be considered when assessing the nature of Northumbrian society in the reign of Ecgfrith. The first is the position of the land charter. Chapter 17 of the Vita Wilfridi records that Wilfrid read out before his congregation the donations of land granted him by Ecgfrith and Ælfwine, which is strongly suggestive that the land charter was known in Northumbria. ${ }^{13}$ Whether charters were introduced into England by Augustine of Canterbury or some seventy years later by Theodore, ${ }^{14}$ Wilfrid would surely have realized

Hunter Blair, Anglo-Saxon Northumbria, ed. M. Lapidge and P. Hunter Blair, Collected Studies Series, CS192 (London, 1984), virI.

$10 \quad V W$, Ch. 17, pp. $36-37$.

11 For current thinking on Wilfrid and a substantial bibliography see N.J. Higham, ed., Wilfrid: Abbot, Bishop, Saint. Papers from the 13ooth Anniversary Conferences (Donington, 2013).

12 Nick Higham, “Northumbria's Southern Frontier: A Review," EME 14 (2006), 391-418, at pp. $414-16$.

$13 V W$, Ch. 17, p. 36. On Wilfrid and land charters see Patrick Sims-Williams, "St Wilfrid and Two Charters dated AD 676 and 68o," Journal of Ecclesiastical History 39 (1988), 163-83.

14 For the early date see Pierre Chaplais, "Who Introduced Charters into England? The Case for Augustine," Journal of the Society of Archivists 3:10 (1969), 526-42, repr. in Felicity Ranger, ed., Prisca Munimenta: Studies in Archival and Administrative History presented to Dr. A.E.J. Hollaender (London, 1973), pp. 88-107. For arguments in favour of Theodore see Ben Snook, "Who Introduced Charters into England? The Case for Theodore and Hadrian," in Textus Roffensis: Law, Language, and Libraries in Early Medieval England, ed. Bruce O'Brien and Barbara Bombi (Turnhout, 2015), pp. 257-89. 
their importance for permitting permanent tenure of land given to the Church. Bede's evidence, however, suggests that its use as a means of ensuring permanent tenure of land granted by a king to laymen was something that was only in the process of coming to fruition in the latter years of Bede's life. ${ }^{15}$

A second factor is the nature of the coinage in Northumbria in the reign of Ecgfrith. Apart from a handful of gold thrymsas associated with southern Northumbria whose date and interpretation is debatable, there is no evidence for monetized trade in Northumbria during Ecgfrith's reign. ${ }^{16}$ Most numismatists and economic historians are in agreement that the development of sceatta coinage in the 8th century was hugely important in the development of trade, but in Northumbria the first evidence of sceattas comes from the reign of Ecgfrith's successor, his half-brother Aldfrith. ${ }^{17}$

The third factor is how the kingdom was administered. There was evidently a political hierarchy in that the expedition to Brega was led by Berht, who is described as a $d u x$ or ealdorman. ${ }^{18}$ Carlisle was administered by a praepositus (?reeve) called Waga. ${ }^{19}$ The Vita Wilfridi mentions praefecti (?also reeves) and sub-kings (subreguli). ${ }^{20}$ The kingdom thus had a basic administrative structure but there is a question as to how far it was underpinned by a literate bureaucracy. It must be remembered that some ecclesiastical foundations dated only from the time of Oswiu. ${ }^{21}$ Whether they were yet ready to provide training of

15 "Epistola Bede ad Ecgbertum episcopum," Ch. 12, in Venerabilis Baedae opera historica, ed. Charles Plummer, 2 vols (Oxford, 1896; repr. in 1 vol., 1969), 1:415-16; translation in EHD 1, pp. 805-06 (no. 170). The only land charter ascribed to Ecgfrith (S 66) is a fabrication, but see Patrick Wormald's valuable introduction to the history of the land charter, Bede and the Conversion of England: The Charter Evidence, Jarrow Lecture 1984 (Jarrow, 1985), esp. p. 17, repr. in idem, The Times of Bede: Studies in Early English Christian Society and its Historian, ed. Stephen Baxter (Oxford, 2006), pp. 135-66, esp. p. 151.

16 James Booth, "Northumbrian Coinage and the Productive Site at South Newbald ('Sancton')," in Early Deira: Archaeological Studies of the East Riding in the Fourth to Ninth Centuries $A D$, ed. Helen Geake and Jonathan Kenny (Oxford, 2000), pp. 83-97, at p. 83; Elizabeth J. Pirie, "Contrasts and Continuity within the Coinage of Northumbria c. 670-876," in Coinage and History in the North Sea World, c. AD 500-1250: Essays in Honour of Marion Archibald, ed. Barrie Cook and Gareth Williams (Leiden, 2006), pp. 211-40, at pp. 217-18.

17 Elizabeth J.E. Pirie, "Finds of 'Sceattas' and 'Stycas' of Northumbria," in Anglo-Saxon Monetary History: Essays in Memory of Michael Dolley, ed. M.A.S. Blackburn (Leicester, 1986), pp. 67-90.

18 Bede, $H E$ IV.26(24), pp. 426-27.

19 VCSA 4.8, pp. 122-23.

$20 \quad V W$, ch. 17, pp. 36-37.

21 Bede, $H E$ III.24, p. 292. 
the kind that the future king Aldfrith received from the Irish ${ }^{22}$ is an open question. The departure for Ireland of many dissatisfied with the outcome of the Synod of Whitby must have been a severe cultural blow for the kingdom. ${ }^{23}$ Monkwearmouth was established by Benedict Biscop only in 679, and Jarrow in 685. The undoubted cultural accomplishments of Northumbrian ecclesiastical foundations did not start to appear until well into the reign of Aldfrith. ${ }^{24}$

On the other hand, we should not underrate the importance that the significant figure of Wilfrid had in shaping the value system of the king and his followers. By successfully persuading Oswiu to accept the Dionysiac Easter, thus marginalizing supporters of the different Christian tradition the Irish brought to Northumbria by portraying its followers as schismatics, ${ }^{25}$ Wilfrid enabled the Irish to be regarded as "the other" and thus easier to attack. Though Ecgfrith was subsequently to oust Wilfrid for adopting the attributes of a king in his style of living, Ecgfrith initially supported him with generous benefactions, as we have seen. In my view, Thomas Charles-Edwards is quite right in emphasizing the importance of Wilfrid's religious views on the kingdom, ${ }^{26}$ even though he was not himself of political importance in Northumbria after he left in 678 to appeal to the pope against his deposition.

These factors suggest to me that Ecgfrith's reign is likely to have followed the style of governance of earlier kings, who maintained the support of their entourage by acquiring booty and by seizing territory whose inhabitants could then be granted as slaves to their followers together with a proportion of the material spoils of war. In attempting to determine the motive for the attack on Brega it is important to bear all these factors in mind.

\section{The Date of the Attack on Brega}

It is unfortunate that ascertaining the date of the attack on Brega from the extant sources is not straightforward. Any resolution of the apparent inconsistencies requires either an element of special pleading or conjecture.

22 Colin A. Ireland, "Where was King Aldfrith of Northumbria Educated? An Exploration of Seventh-Century Insular Learning," Traditio 70 (2015), 29-74.

23 Bede, $H E$ Iv.4, p. 346; Vera Orschel, "Mag nEó na Sacsan: An English Colony in Ireland in the Seventh and Eighth Centuries," Peritia 15 (2001), 81-107.

24 Ireland, "King Aldfrith," 30.

25 In $V W$, ch. 5, pp. 12-13, his biographer refers to "the Easter rule, of which the British and Irish schismatics (scismatici) were ignorant."

26 T.M. Charles-Edwards, Wales and the Britons 350-1064 (Oxford, 2013), p. 409, though he reaches different conclusions from me about Ecgfrith's intentions in invading Ireland. 
Bede states unambiguously that Ecgfrith's father, Oswiu, died on 15 February 670, "leaving his son Ecgfrith as heir to the kingdom" and confirms the year in his chronological summary. ${ }^{27} \mathrm{He}$ reports in this summary that Ecgfrith was killed in 685 . He had implied this date earlier when, after giving 684 as the year of Ecgfrith's attack on Brega, he later in the same chapter declares that "the very next year" Ecgfrith led an army to ravage the Picts and was killed by them on 20 May "in the fortieth year of his age and the fifteenth of his reign." ${ }^{28}$ That Bede was accurate in ascribing his death to the fifteenth year finds confirmation in the dedication inscription for the church of St Paul at Jarrow, which has survived. This records that the monastery was dedicated on the gth kalends of May (i.e. 23 April) in the fifteenth year of king Ecgfrith and the fourth of abbot Ceolfrith. The ninth day was on a Saturday in 684 but fell on a Sunday, the appropriate day for such a dedication, in the year $685 .{ }^{29}$

The most convincing solution, to my mind, is that formulated by Kenneth Harrison, namely Ecgfrith did not immediately succeed his father until sometime in September $670 .{ }^{30}$ I suggest that an explanation lies to hand for a delayed accession. Ecgfrith had an elder brother, Alhfrith, who supported Wilfrid in his prosecution of the Roman cause at Whitby. In that context, Alhfrith is described as a king, presumably of Deira. Bede mentions in passing that Alhfrith had rebelled against his father. ${ }^{31}$ It is usually assumed that Alhfrith was either killed or had died since he is not mentioned in the historical record after A.D. 664 but this was not necessarily the case. Because of Alhfrith's rebellion, Ecgfrith may well have been Oswiu's designated successor, ${ }^{32}$ but if Alhfrith had, in fact, survived, as the elder brother of Ecgfrith he could well have laid claim to the throne,$^{33}$ a claim that may have taken some months to resolve. Although Bede strongly disapproved of Ecgfrith's attack on the Irish, he may

27 Bede, $H E$ IV.5 and v.24, pp. 348-49 and 564-65.

28 Bede, $H E$ IV.26(24), pp. 426-29.

29 Elizabeth Okasha, Hand-List of Anglo-Saxon Non-Runic Inscriptions (Cambridge, 1971), pp. 85-86 (with extensive bibliography up to 1965) and Plate 61; John Higgitt, "The Dedication Inscription at Jarrow and its Context," AntJ 59:2 (1979), 343-74 (with a few readings slightly different from Okasha's and an extensive discussion of script and textual affinities) and pl. LX $a$ and $b$, opp. p. 358; Ian Wood, The Origins of Jarrow: The Monastery, the Slake and Ecgfrith's Minster, Bede's World Studies 1 (Jarrow, 2008), pp. 2-3 and n. 2.

$30 \quad$ "The Reign of King Ecgfrith of Northumbria," Yorkshire Archaeological Journal 43 (1971), 79-84. For an alternative viewpoint see Susan Wood, "Bede's Northumbrian Dates Again," EHR 98 (1983), 280-96.

31 Bede, $H E$ III.14, pp. 254-55.

32 For the concept of designation, see Harrison, "Reign," p. 83 and n. 1.

33 Professor Higham assumes that Alhfrith was not available: see N.J. Higham, Ecgfrith: King of the Northumbrians, High-King of Britain (Donington, 2015), p. 126 n. 21. 
well not have wanted to impugn Ecgfrith's claim on the throne by mentioning Alhfrith in this context since Ecgfrith had been so centrally involved in the creation of Bede's own monastery at Jarrow.

Unfortunately one looks in vain to the Irish Annals, which fail to clarify the chronology. The text of the Annals of Ulster actually gives A.D. 684 as the year of the attack, but in fact, the date of the attack on Brega in the Annals of Ulster, Annals of Roscrea, Annals of Tigernach, Chronicon Scottorum, Fragmentary Annals, and McGeoghagan's Book (= Annals of Clonmacnoise), whose entries are all cognate, synchronize at A.D. 685 , as Daniel McCarthy has shown. ${ }^{34}$ Likewise several sets of annals synchronize Ecgfrith's death at A.D. 686, with the Annals of Ulster and Tigernach stating that Ecgfrith "had completed the 15th year of his reign" and giving a non-Julian date, "Saturday, May 2oth," as the specific day of his death. ${ }^{35}$ Since 20 May 686 fell on Sunday, whereas 20 May 685 indeed fell on Saturday, Dr Mc Carthy has suggested to me that the one-year postdating of these two entries in these annals implies they were entered retrospectively. As for the claim that at his death Ecgfrith had completed the fifteenth year of his rule, I would suggest this is best explained by the annalist's imposing a damnatio memoriae on a failed contestant for the throne, thus dating Ecgfrith's succession to the death of Oswiu (February 670).

My conclusion is thus that Bede's dating of A.D. 684 for the attack should be accepted in spite of the seeming conflicts between the early medieval sources.

\section{Captivi}

Adomnán, abbot of Iona, mentions in passing two visits to Northumbria subsequent to Ecgfrith's death but only in the context of a pestilence that was afflicting both Britain and Ireland. In his view God protected him from this plague "in England, when we visited our friend king Aldfrith ... both in our first visit, after the battle of Ecfrith, and in our second visit, two years later." ${ }^{36}$ As he is focusing on the fact that he was spared from infection, Adomnán can

34 Available at $<$ www.scss.tcd.ie/misc/kronos/chronology/synchronisms/Edition_4/K_trad/ Synch_tables/so679-0694.htm $>$ (accessed 28 Feb. 2017)

35 "uicisimo die mensis Maii, Sabbati die ... .x.u. ${ }^{\circ}$ anno regni sui consummata": $A U$, pp. 148-49.

36 Adomnán's Life of Columba (hereafter AVc), 2.46, ed. and trans. Alan Orr Anderson and Marjorie Ogilvie Anderson (Oxford, 1991), pp. 178-79 (103b). On Aldfrith see Barbara Yorke, Rex doctissimus: Bede and King Aldfrith of Northumbria, Jarrow Lecture 2009 (Newcastle on Tyne, 2009) and Ireland, "King Aldfrith," together with the references they cite. 
tactfully avoid mentioning the reason for one of these visits, presumably because he is keen to rebuild the bridges between Irish clerics and Northumbria that had been swept away by the torrent of Wilfrid's eloquence at the Synod of Whitby. With Wilfrid effectively banished since 678 and Aldfrith, a former resident of Iona with strong Irish ties, now the king of the Northumbrians, it was not necessary to drag to the surface the attack on Ireland that Ecgfrith had fomented in 684. Fortunately the Irish Annals succinctly report that in 687 (recte 686) Adomnán brought back sixty captives to Ireland. ${ }^{37}$

The much later Fragmentary Annals of Ireland confirms that these were people taken by the Saxons: "In this year Adamnán set free the captives the Saxons had taken from Ireland." 38 It is important to note here that the text uses (in a Middle Irish form) the Old Irish brat whose range of meanings includes 'captive(s) as spoil', 39 though not 'hostages'. Irish law was familiar with the concept of hostages, but the word for an intertribal hostage appears to have been giall. ${ }^{40}$ Since Ecgfrith himself was held as a hostage in the kingdom of the Mercians at the time when his father successfully defeated Penda in $655,{ }^{41}$ one can understand why it might be assumed that such captives were taken as hostages. (It should be noted, however, that Bede uses the word obses, not captiuus, to describe Ecgfrith's status.)

We are fortunate, however, in having a contemporary source that enables us to interpret how the word captiuus was used by an Irishman in the late 7th century. Adomnán, who died in 704, composed his Life of Columba perhaps little more than a decade after Ecgfrith's death. In that work he uses the words captiua and captiuus three times in fairly unambiguous contexts. The first concerns Columba's contact with a magician called Broichan, who possessed an Irish female slave whom Columba urged him to free. "Know this, Broichan, know that if you will not release for me this pilgrim captive (captiuam) before

37 For example, "Adomnanus captiuos reduxit ad Hiberniam .lx.," $A U$, pp. 150-51. All synchronize on the same date of A.D. 687, a discrepancy of one year.

38 "Isin bliadain si ro fuaslaig Adhamhnán an braid rugsad Saxain a hErinn": Joan Newlon Radner, ed., Fragmentary Annals of Ireland (Dublin, 1978), pp. 36-37.

39 Also "act of plundering, robbing; spoil, plunder, robbery." Available at EDIL -Electronic Dictionary of the Irish Language, s.v. "1 brat" (accessed 27 Nov. 2017). My thanks to Dr Colin Ireland for advice on this word.

EDIL, s.v. "2 gíall (a)” (accessed 27 Nov. 2017). Robin Chapman Stacey, "The Hostage-Sureties of Irish Law," in eadem, The Road to Judgment: From Custom to Court in Medieval Ireland and Wales, Middle Ages Series (Philadelphia, 1994), pp. 82-111 and notes, pp. 258-69.

Bede, $H E$ III.24, p. 290. 
I depart from this province, you shall presently die." 42 That the Latin captiua here is a virtual synonym for a slave is indicated by Adomnán's words, where he rings the changes in his choice of vocabulary to describe her status: she is a serua (used twice), an ancellula, a seruula, a famula (used twice). In a second story, Columba gives an indigent man a miraculous stake whose property is consistently to impale animals and thus provide the man's family with food and income. His wife urges him, however, to destroy it because if people or cattle are killed by it, " $\mathrm{Y}]$ ou yourself and I, with our children, will either be put to death, or be led into slavery."43 A third incident concerned Librán, a man who had killed someone and had been put in chains, but had been redeemed by a kinsman; on his release Librán agreed to serve the one who freed himbut had then run away to Iona. After doing seven years' penance Columba sent him back to his owner, predicting to him that, following the advice of his owner's wife, "he will ... grant you liberty ... unloosing according to custom the captive's belt from your loins." 44 In all three cases it is clear that captiuus and captiua are virtual synonyms for a slave. As with Bede, Adomnán uses the word obsides to refer to hostages. ${ }^{45}$ The meaning 'person taken as a slave' is fortified by the development of a metaphorical sense in later Irish writers: 'to enslave spiritually'.46

It is nigh impossible to give a clear definition of slavery in Northumbria at this period, but two aspects of existence can be said to have been a reality for these captives. The first is the inevitable consequence of being taken away from their homeland: they would have been deprived of the support of

42 "Scito Broichan scito quia si mihi hanc perigrinam libe $<$ ra $>$ re captiuam nolueris priusquam de hac reuertar prouincia, citius morieris": AVC 2.33, pp. 140-41 (79b).

43 "[T] ipse et ego cum nostris liberis aut occidemur aut captiui ducemur": AVC 2.37, pp. ${ }^{150-51}$ (84b). Richard Sharpe concurs with their translation: "[T] hen you and I and our children will be killed or led into slavery": Adomnán of Iona, Life of St Columba, trans. Richard Sharpe, Penguin Classics (Harmondsworth, 1995), pp. 186 and 337 n. 305, where, citing Fergus Kelly, A Guide to Early Irish Law, Early Irish Law Series 3 (Dublin, 1988), pp. $215^{-16}$, he points out that a victim's family could demand that someone who was unable or unwilling to pay the penalty for unlawful killing could choose to have the killer killed or enslaved.

44 "[L]ibertate donabit, cingulum ex more captiui de tuis resoluens lumbis": AVC 2.39, pp. 156-57 (89a) and cf. Sharpe, trans., Life of St Columba, pp. 190 and 340 n. 315.

$45 \quad A V C 2.42$ (95a), pp. 166-67.

46 Anthony Harvey and Jane Power, The Non-Classical Lexicon of Celtic Latinity, 1: Letters A-H, Royal Irish Academy Dictionary of Medieval Latin from Celtic Sources, Constituent Publications 1 (Turnhout, 2005), p. 109, s.v. "captiuare," who cite Sedulius Scottus, Collectanea in omnes B. Pauli epistolas, in Patrologia Latina, ed. Jacques-Paul Migne (1844-65), 103:203A and Iohannes Scottus Eriugena, De diuisione naturae (Periphyseon), lib. V, in Patrologia Latina 122:972A. 
kinsmen. The second is the humiliating nature of the status of being a slave. With his customary acuity, James Campbell drew out the implications of a passage about captives recorded by Bede: "When Bede described a vision of hell the image which came to his mind was that of captives being led off into slav-

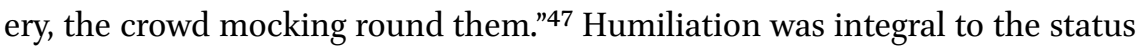
of a slave, as the contemporary West-Saxon Laws of Ine make plain: in the case of slaves, misdemeanours were to be punished by beating, unlike freemen, who could compound for wrongs committed. ${ }^{48}$

We should thus see those captured in the raid on Brega as no different from material forms of booty. They were available to be granted by royal pleasure to supporters, to be employed as their new owners pleased. Their position was potentially more parlous than those whose territory in England had been overrun by conquering Anglo-Saxons, however, in that they would not have had kindred who might provide them with support.

How did Adomnán come to be the intermediary in securing the release of these persons in 686 ? As often with historical events, we should look to a combination of factors. As abbot of Iona, he was a member of a confederacy of monasteries, including Durrow, west of Brega. Several times Adomnán mentions contacts with Durrow..$^{49}$ The monastery of Rechru, which appears to have been on what is now called Lambay Island, was claimed in later sources to be part of Columba's familia. ${ }^{50}$ We do not know which ecclesiastical foundations were attacked, but being off the coast of Brega Lambay Island was particularly vulnerable. We can thus envisage that representations were made to Adomnán from the churches affected in Brega, either through Durrow or directly, to intervene to secure the release of those who had been seized in 684. And since Aldfrith, who had succeeded Ecgfrith as king, had been resident at Iona,

47 "Early Anglo-Saxon Society According to Written Sources," in his Essays in Anglo-Saxon History (London and Ronceverte, WV, 1986), p. 138; originally published (in German) in Claus Ahrens, ed., Sachsen und Angelsachsen (Hamburg, 1978), pp. 455-62; cf. J. Campbell, "Elements in the Background to the Life of St Cuthbert and his Early Cult," in St Cuthbert, his Cult and his Community to AD 1200, ed. Gerald Bonner, David Rollason, and Clare Stancliffe (Woodbridge, 1989), pp. 3-19, at p. 5. The passage in Bede, $H E$ v.12, pp. 490-93 reports Dryhthelm describing the lamentation of "captured foes."

48 Ine 3.1, 48, 54.2, in Die Gesetze der Angelsachsen, ed. Felix Liebermann, 3 vols (Halle, 190316), 1:90, 110, 114 .

49 For arguments in favour of Adomnán's having personal knowledge of Durrow see Alfred P. Smyth, Celtic Leinster: Towards an Historical Geography of Early Irish Civilization A.D. 500-160o (Dublin, 1982), pp. 118-19. On his Irish midlands links see Ireland, "King Aldfrith," pp. 51, 52, and n. 129 .

5o Máire Herbert, Iona, Kells, and Derry: The History and Hagiography of the Monastic Familia of Columba (Oxford, 1988), p. 42. 
Adomnán had good reason to visit the new king in order to repair the relations between the Irish and the Northumbrians that had been damaged by Ecgfrith's instigation of the invasion of Brega. Equally Wilfrid's prosecution of the Roman cause had created rifts between those with sympathy for Ionan ecclesiastical practice and those devoted to the Dionysiac Easter.

The Annals of the Four Masters rather gilds the lily in its account of Adomnán's visit:

Adamnan went to England, to beg for the captives [braite] that the North Saxons had taken with them from Mag-Breg, in the previous year. He got their restitution from them after doing miracles and wonders before the hosts; and afterwards they gave him great honour and reverence, with complete restoration of everything he asked of them. ${ }^{51}$

This has all the marks of an oral tale that has grown in the telling. The story is taken even further in the Three Fragments. The latter asserts that Adomnán was given the booty seized consequent on his receiving the crown-tonsure in Northumbria, ${ }^{52}$ a claim made presumably on the basis of a letter of Ceolfrith to Nechtan, king of the Picts, cited in Bede's Historia Ecclesiastica v.21. There Ceolfrith reports that when Adomnán "was sent on a mission from his people to King Aldfrith and wished to see our monastery," Ceolfrith reproved him for wearing the Celtic tonsure. He mentions that Adomnán subsequently led large numbers in Ireland to "the catholic observance of Easter," but carefully avoids saying that he personally adopted the tonsure of St Peter. ${ }^{53}$

Ceolfrith's letter reports only a single visit by Adomnán to Northumbria but his focus was on the crown tonsure issue. Six of the Irish annals record a visit to redeem captives; only the Annals of Tigernach and Annals of Roscrea report (in almost the same terms as their first entry) a second visit two years later. ${ }^{54}$

51 Annála Ríoghachta Éireann: Annals of the Kingdom of Ireland by the Four Masters from the Earliest Times to the Year 1616, ed. and trans. J. O'Donovan, 2nd ed., 7 vols (Dublin, 1856), 1:290-93, s.a. 684; also translated in Early Sources of Scottish History, A.D. 500 to 1286, collected and trans. by Alan Orr Anderson, 2 vols (Edinburgh, 1922; repr. Stamford, 1990), 1:196.

52 Annals of Ireland: Three Fragments, copied from Ancient Sources by Dubhaltach mac Firbisigh, ed. with a translation and notes by J. O'Donovan (Dublin, 1860), pp. 112-15; cited in translation in Early Sources, ed. Anderson, 1:196 n. 3.

53 Bede, $H E$ v.21, pp. 550-51.

54 For the references see n. 34 above. In the second entry "in (H)iberniam" replaces "ad Hiberniam." Dr Mc Carthy has suggested to me that two different sources were being drawn upon. For the texts see Whitley Stokes, ed. "Annals of Tigernach. Third Fragment A.D. 489-766," Revue celtique 17 (1896), 119-263, at pp. 210 and 211. Also Bart Jaski and Daniel Mc 
As mentioned above, Adomnán said he made two visits, the second being two years after the first. Daniel Mc Carthy has shown that Adomnán was not an altogether reliable chronographer ${ }^{55}$ but it is difficult to see why he should be inaccurate here. The annalistic sources imply, however, that only one visit involved negotiating for the release of the Irish captives.

\section{Motive}

Ecgfrith's defeat at the Battle of the River Trent in 679 must not only have been a blow to the Northumbrian people but also a devastating triple blow for Ecgfrith. ${ }^{56}$ First, he had lost his eighteen-year-old brother, a potential preserver of the dynasty should Ecgfrith die. Second, he had lost the territory of Lindsey and, since the truce between him and Æthelred, king of the Mercians, had been negotiated by Archbishop Theodore of Canterbury, he could hardly renege on the agreement because Theodore had supported him over the deposition of Wilfrid. ${ }^{57}$ The lands in Lindsey and its revenues that might have been at his disposal as its overlord were now lost to him - and to those on whom he might have bestowed them. ${ }^{58}$ Perhaps most serious of all was something that is not discussed in the sources but which should also be taken into account. Like many leaders in all spheres of life and all periods, early medieval kings were dependent on charisma: those indefinable aspects of personality that empowered them to lead others. In a society characterized by war and religion, a significant defeat such as this one must have led to doubts and questions about Ecgfrith's rulership and whether he had Divine support for it.

We cannot say for sure what factors were at play in the years following his defeat in 679 , but one further matter should at least been borne in mind. With expansion to the south-east brought to a halt, one would have expected Ecgfrith to have turned his attention to the north-west to enlarge his realm. Yet it has been noted that Christian memorials showing Anglo-Saxon influence

Carthy, "A Facsimile Edition of the Annals of Roscrea," p. 44. Available at <https://scss.tcd. ie/misc/kronos/editions/AR_portal.htm> (accessed 2 Feb. 2017).

"The Chronology of Saint Columba's Life," in Early Medieval Ireland and Europe: Chronology, Contacts, Scholarship. Festschrift for Dáibhi Ó Cróinín, ed. Pádraic Moran and Immo Warntjes, Studia Traditionis Theologiae 14 (Turnhout, 2015), pp. 3-32.

$5^{6}$ On the political dimensions of the defeat see Higham, Ecgfrith, esp. pp. 179-82.

57 See also N.J. Higham, “Theodore's Peace," above, pp. 197-213.

58 For this region, see Christopher Loveluck et al. Rural Settlement, Lifestyles and Social Change in the Later First Millennium AD: Anglo-Saxon Flixborough in its Wider Context, Excavations at Flixborough 4 (Oxford, 2007). 
seem to stop at the River Cree, to the west of which lay Whithorn. ${ }^{59}$ AngloSaxon expansion into Whithorn seems to have taken place later, with a bishopric being established there shortly before $73{ }^{60}$ It is puzzling that Ecgfrith seems not to have expanded his territorial boundaries to encompass Whithorn-unless he encountered some serious opposition in that region.

However we explain the passage of time between late 679 and the attack on Brega in June 684, I suspect that the invasion of Ireland was dictated by socioeconomic factors rather than political ones. Some scholars have thought otherwise. Alfred Smyth suggested that Aldfrith might have been associated with Durrow and the Southern Uí Néill: "Ecgfrith then would have launched a punitive raid against the Southern Uí Néill in the belief that they had harboured his rival and older brother for many years." ${ }^{61}$ Hermann Moisl in a closely argued article that has had wide influence asserted that in 685 "the Uí Néill took part in the Pictish-Irish revolt against Ecgfrith ... to support the claim of their kinsman Aldfrith to the Northumbrian kingship; Ecgfrith, realizing what was afoot, made a preemptive strike against the Uí Néill."62 Barbara Yorke has observed that there are Northumbrian sources suggesting a different interpretation of how Aldfrith succeeded to the throne. ${ }^{63}$ And I share Thomas Charles-Edwards's hesitancy in accepting that an attack on the Southern Uí Néill would have motivated the Northern Uí Néill to take revenge a year later, especially given the constant internecine strife between ruling families in Ireland. ${ }^{64}$

What we are being asked to believe is that Ecgfrith attacked Brega and took unnamed (and thus quite possibly politically unimportant) prisoners (Moisl's word) in order to put pressure on the Northern Uí Néill not to support the

59 Nicola J. Toop, "Northumbria in the West: Considering Interaction through Monumentality," in Early Medieval Northumbria: Kingdoms and Communities, AD 450-110o, ed. David Petts and Sam Turner (Turnhout, 2011), pp. 85-112, at pp. 98-100. I have not seen Derek Craig's 1992 Durham doctoral thesis "The Distribution of Pre-Norman Sculpture in Southwest Scotland: Provenance, Ornament and Regional Groups," which informed Toop's observations.

6o See Toop, "Northumbria in the West," esp. Plate Ib opp. p. 178. For the literary and historical evidence of Northumbria's westward expansion see Rosemary Cramp, Whithorn and the Northumbrian Expansion Westwards, Third Whithorn Lecture, 17th September 1994 (Whithorn, 1995) and for archaeological evidence about early Whithorn see Peter Hill, Whithorn and St Ninian: The Excavation of a Monastic Town, 1984-91 (Stroud, 1997).

61 Smyth, Celtic Leinster, p. 121.

62 Hermann Moisl, "The Bernician Royal Dynasty and the Irish in the Seventh Century," Peritia 2 (1983), 103-26, at p. 123.

63 "Adomnán at the Court of King Aldfrith," in Adomnán of Iona: Theologian, Lawmaker, Peacemaker, ed. Jonathan M. Wooding et al. (Dublin, 2010), pp. 36-50, at pp. 37-38.

64 The Chronicle of Ireland, trans. T.M. Charles-Edwards, Translated Texts for Historians 44, 2 vols (Liverpool, 2006), 1:165, n. 6. 
claims of Aldfrith on the Northumbrian kingship (for which there appears to be no evidence, unless one interprets a remark by the 12th-century historian William of Malmesbury that Aldfrith "had been regarded by the nobles although the elder as unworthy of the throne") ${ }^{65}$ It is puzzling then why Ecgfrith did not just attack Iona in 684, since this is where Aldfrith appeared to have been residing. Nicholas Higham emphasizes the growing power of Fínsnechtae Fledach and detects "an intermeshing of friendships and hostilities around the North Channel, with Brega, Clyde Rock and Fortriu pursuing parallel objectives and probably in alliance." In his view, this prompted the Northumbrian expedition which led to the seizing of hostages. ${ }^{66}$

I would prefer the judicious application of Occam's Razor. Rather than complex arguments based on the alleged threats posed by Aldfrith or Fínsnechtae Fledach, I suggest that Ecgfrith was behaving like other Anglo-Saxon kings who preceded him. Any ruler requires supporters in order to retain power. For an early medieval king, this meant that his followers needed material rewards in the form of precious objects and the manpower necessary to provide the food and services attendant on their status.

Brega was an agriculturally rich region easily accessible from the sea. At this time its churches were most likely still wooden structures ${ }^{67}$ and so easy targets, especially since their communities could be portrayed as schismatics who did not follow the true date of Easter. Cogitosus' Life of Brigit, probably composed in the mid-7th century, ${ }^{68}$ helps explain why ecclesiastical establishments especially were attacked. According to him the tombs of Brigit and her bishop Conleth in the church in Kildare were "adorned with a refined profusion of gold, silver, gems and precious stones with gold and silver chandeliers hanging from above." He also records that Brigit had shattered a silver chalice into three equal pieces to hand to the poor. Given the political importance and evident wealth of Brega it is not unreasonable to suggest that its churches were possessed of similar lavish trappings. Some may even, like Brigit's church, have kept "the treasures of kings." 69

\footnotetext{
65 WM, GRA, §52, pp. 80-81.

66 Higham, Ecgfrith, pp. $201-07$ at p. 204 and p. 26.

67 Peter Harbison, "Early Irish Churches," in Die Iren und Europa im früheren Mittelalter, ed. Heinz Löwe, Veröffentlichungen des Europa Zentrums Tübingen, Kulturwissenschaftliche Reihe, 2 vols (Stuttgart, 1982), 2:618-29.

68 Sean Connolly and J.-M. Picard, "Cogitosus's Life of St Brigit," Journal of the Royal Society of Antiquaries of Ireland 117 (1987), 5-27, at p. 5 .

69 Patrologia Latina 72:789A (church), 786A-B (chalice), and $790 \mathrm{~B}$ (treasures of kings) (texts) and Connolly and Picard, "Cogitosus's Life," pp. ${ }_{25}$ Ch. 32.1, 22-23 Ch. 27.1-4, and 26 Ch. 32.9 (translations).
} 
The intricate Tara Brooch, discovered at Bettystown, on the coast of Brega just south of Drogheda, which may be dated to $c .700$, shows that Cogitosus was not simply engaging in hyperbole..$^{70}$ Obviously the techniques evident in the Brooch did not arise ex nihilo at the beginning of the 8th century: they were part of a tradition stretching back to at least the late 6th century, as the Ballinderry Brooch of $c .600$ with its enamel and millefiori decoration attests. ${ }^{71}$ Ecclesiastical objects such as book covers and book shrines, and more idiosyncratic objects such as the 8th-century Moylough Belt Shrine from Co. Sligo ${ }^{72}$ point to the diversity of items that might be found in churches. Then there was the wealth that could be seized from individuals. The valuable objects that were available for looting were diverse, for instance, horse bridles of gold and silver, which were marks of status. ${ }^{73}$ Objects of personal adornment such as penannular brooches must also have been tempting targets for looters. ${ }^{74}$

An attack on Brega thus offered the possibility of obtaining booty in the form of goods and persons that Ecgfrith could distribute to his followers at a minimum cost to himself. It was something of a masterstroke. If Berht and his men had failed and been killed ... well, that would have been unfortunate and Ecgfrith's prestige may have suffered-but they would not have been present to remind him of their failure. Even had they been captured, they could have been portrayed as the ones who had failed.

$70 \quad$ Niamh Whitfield, "The Filigree of the Hunterston and 'Tara' Brooches," in The Age of Migrating Ideas: Early Medieval Art in Northern Britain and Ireland. Proceedings of the Second International Conference on Insular Art held in the National Museums of Scotland in Edinburgh, 3-6January 1991, ed. R. Michael Spearman and John Higgitt (Edinburgh and Stroud, 1993), pp. 118-27; the putative date of the Tara brooch is discussed at p. 126.

71 For an illustration and discussion see Fintan O'Toole, $A$ History of Ireland in 100 Objects (Dublin, 2013), no. 26.

72 O'Toole, History of Ireland, no. 32. Peter Harbison's posited later dates for the Tara Brooch (middle or latter part of the eighth century) and the Belt Shrine (A.D. $750 \times 850$ ) do not affect my general argument even if they be accepted by other scholars: "The Date of the Moylough Belt Shrine," in Irish Antiquity: Essays and Studies Presented to Professor M.J. O'Kelly, ed. Donnchadh Ó Corráin (Cork, 1981, repr. Dublin, 1994), pp. 231-39.

73 Críth Gablach, ed. D.A. Binchy, Mediaeval and Modern Irish Series 11 (Dublin, 1941), p. 16, Ch.27.407, discussed by Fergus Kelly, Early Irish Farming: A Study based mainly on the LawTexts of the 7 th and 8th Centuries AD, Early Irish Law Series 4 (Dublin, 1997), p. 89. On silver in Ireland see Michael Ryan, "Some Archaeological Comments on the Occurrence and Use of Silver in Pre-Viking Ireland," in Studies on Early Ireland: Essays in Honour of M.V. Duignan, ed. B.G. Scott ([Dublin], n.d. [1981?]), pp. 45-50.

74 Most of the objects in this paragraph are illustrated in Françoise Henry, Irish Art in the Early Christian Period (to 800 A.D.), rev. ed. (London, 1965); metalwork is discussed in Ch. 5 (pp. 92-116). 


\section{Northumbrian Reactions to the Attack}

Historians are primarily dependent upon written sources and inevitably there is a risk that the values and judgments of their sources shape their interpretation of events. To historians of early Anglo-Saxon England Bede is such a towering figure that his interpretation of events can easily colour our views. Bede did not take a neutral position over the attack on Brega as is evident from his condemnation of it quoted earlier. ${ }^{75}$ The consequences of Ecgfrith's subsequent death at the hands of the Picts are given epic status by Bede with a quotation from Virgil, Aeneid 2.169: "From this time the hopes and strength of the English kingdom began to 'ebb and fall away'."76

We must remember that Bede was writing over four decades after the event and from a perspective on the Irish that, while nuanced, was favourable. ${ }^{77}$ It is worth considering what Ecgfrith accomplished in the eleven months following the attack on Brega. In 685 he had encouraged the consecration of Cuthbert as bishop. This was no ex cathedra decision on his part: a "synod of no small size" assembled in his presence and, presided over by Archbishop Theodore no less, elected Cuthbert. When Cuthbert failed to respond but remained at the monastery on Farne, Ecgfrith sailed there with Bishop Trumwine "as well as many other religious and powerful men," the word "powerful," potentibus, implying support by the secular leaders of the time. ${ }^{78}$ As has already been discussed Ecgfrith was also commemorated in the foundation stone at Jarrow, the consecration of the church taking place just the month before his death. Thus it is clear that Ecgfrith continued in an intimate relationship with ecclesiastical leaders following his attack on Brega. And the support of his secular elite was implied not just by their presence at the synod that elected Cuthbert but also by their willingness to follow him on his fatal venture into Pictland.

There is one other source that has been deemed possibly to be relevant, though it is extremely problematic. In the Fragmentary Annals of Ireland

75 Bede, $H E$ IV.26(24), pp. 426-29.

76 "Ex quo tempore spes coepit et uirtus regni Anglorum 'fluere ac retro sublapsa referri': Bede, $H E$ IV.26(24), pp. 428-29.

77 For the complexities of Bede's attitude to the Irish see A.T. Thacker, "Bede and the Irish," in Beda Venerabilis: Historian, Monk \& Northumbrian, ed. L.A.J.R. Houwen and A.A. MacDonald, Mediaevalia Groningana 19 (Groningen, 1996), pp. 31-59.

78 Bede, $H E$ IV.28(26), pp. 436-37, an account substantially supported by the earlier Vita $S$. Cuthberti Anonyma, 4.1, in Two Lives of Saint Cuthbert: A Life by an Anonymous Monk of Lindisfarne and Bede's Prose Life, ed. and trans. Bertram Colgrave (Cambridge, 1940, repr. 1985), pp. 110-11; cf. also Bede, Vita Sancti Cuthberti, in the same volume, Ch. 24, pp. 238-39. 
following an entry on "[t]he death of Flanna Fína, son of Oswy, king of the Saxons" there is a three-quatrain poem of twelve lines in total by an otherwise unknown poet, Riagail of Bennchor (Bangor, Co. Down) that sings of a battle fought by Bruide. Flann Fína was the Irish name of Aldfrith, Ecgfrith's alleged half-brother and successor. Though Bruide mac Derile, king of the Picts, died in A.D. 704, two years after the death of Aldfrith, there is no suggestion in Anglo-Saxon sources that Aldfrith died in battle. The poem most likely refers to the death of Ecgfrith at the hands of Bruide mac Bili, king of the Picts (A.D. 672-693). ${ }^{79}$ James Fraser, with commendable caution, notes that "it is possible to read" the poem as indicating that a backlash led the king "to make some kind of public show of remorse." I would instead interpret the lines translated as "even though he did penance | and that too late in Iona" as poetic licence, implying that Ecgfrith's interment at the Irish monastery of Iona was a kind of posthumous penance (exile being one form of penance for killing). The poem is clearly a later confection ultimately from a source hostile to Ecgfrith which in my view does not provide credible evidence of his behaviour after Brega. ${ }^{80}$

There is no evidence that the Northumbrian contemporaries of Ecgfrith reacted with hostility to his assault on Brega. On the contrary, the literary sources portray him as ruling as a proper Christian Anglo-Saxon king should, attending an important synod called to elect a new bishop and receiving advice-even if he chose not to take it.

With his successful onslaught on Brega, Ecgfrith had engineered a foreign victory and thereby had acquired additional means to support his warrior entourage. This success evidently gave him the confidence to himself lead an invasion force into Pictland the next year. It was a decision that was a fatal misjudgement.

79 "Mors Flainn Fiona mc. Ossa, rí Saxan": Radner, ed., Fragmentary Annals, pp. 54-55, no. 165. Radner evidently understood the poem to refer to Aldfrith as she identifies the Pictish king as "Bruide m. Deril" (see ibid., p. 213). Cf. Ireland, "King Aldfrith," pp. 44-45.

80 James E. Fraser, The Pictish Conquest: The Battle of Dunnichen 685 and the Birth of Scotland (Stroud, 2006), p. 46. See further Wadden's discussion of this source: "First English Invasion," pp. 9-10. 